\title{
LATE QUATERNARY NUPELA TAXA OF RETEZAT MTS (S. CARPATHIANS), WITH DESCRIPTION OF NUPELA POCSII SP. NOV. (BACILLARIOPHYCEAE)
}

\author{
Krisztina BuczKó ${ }^{1}$, AgAta Z. WoJTAl \& ENIKÖ K. MAgYARI
}

\begin{abstract}
Nupela pocsii Buczkó \& Wojtal, sp. nov., a new species from the Retezat Mountains (S. Carpathians), is described. High asymmetry (along apical and transapical axes and in raphe pattern) and small dimensions are the most characteristic features of this taxon. Nupela pocsii was found during paleolimnological research in early Holocene sediment of Lake Brazi. Seven other representatives of the genus Nupela were detected in high-resolution diatom analyses of three lake sediment sequences of the Retezat Mts: Nupela fennica (Hustedt) Lange-Bertalot, N. imperfecta (Schimanski) Lange-Bertalot, N. impexiformis (Lange-Bertalot) Lange-Bertalot, $N$. lapidosa (Krasske) Lange-Bertalot, $N$. paludigena (R. P. Scherer) Lange-Bertalot, $N$. vitiosa (Schimanski) Siver \& Hamilton and an unidentified Nupela Vyverman \& Compere species. Our results suggest high diversity of oligotraphenic species in these mountain lakes during their ontogeny, which began 17,000-15,000 years ago. In addition to the newly described species this is also the first record of $N$. paludigena in European lakes, although its occurrence was previously documented by SEM and LM from Lake Saint Anna without correct identification.
\end{abstract}

Key words: diatoms, Nupela, oligotrophy, paleolimnology, Retezat Mountains, South Carpathians

Krisztina Buczkó, Department of Botany, Hungarian Natural History Museum, Könyves Kálmán krt. 40. H-1476 Budapest, Hungary; e-mail: krisztina@buczko.eu

Agata Z. Wojtal, Department of Phycology, W. Szafer Institute of Botany, Polish Academy of Sciences; Lubicz 46, 31-512 Kraków, Poland; e-mail:a.wojtal@botany.pl

Eniko K. Magyari, Research Group for Paleontology, Hungarian Academy of Sciences - Hungarian Natural History Museum, Budapest, Pázmány Péter sétány, 1/C Hungary; e-mail: emagyari@caesar.elte.hu

\section{INTRODUCTION}

The genus Nupela was erected by Vyverman and Compére in 1991 and since then the number of its representatives has gradually increased, due in part to transfers of already known species from the genera Achnanthes, Brachysira, Navicula and Neidium to Nupela, and in part to the description of several new species (e.g., Monnier et al. 2003; Potapova et al. 2003; Kulikovskiy et al. 2009; Wojtal 2009; Siver et al. 2010; Bahls 2011; Potapova 2011b). In AlgaeBase there are 43 records of Nupela taxa listed (Guiry \& Guiry 2013), and 48 species names are found in the California Academy of Sciences Catalogue of Diatom Names (http://research.calacademy.org).

\footnotetext{
1 Corresponding author
}

Bahls (2011) recently summarized the history of the genus, including its modified definition. The most distinctive feature of Nupela seems to be the larger external openings of the areolae relative to the internal openings (Spaulding \& Edlund 2008). Species of Nupela are small, generally smaller than $20 \mu \mathrm{m}$. The valves can be broad or narrow, iso- or heterovalvar with respect to raphe development and/or shape of the central area, and sometimes tend to be dorsiventral, with the raphe displaced toward the primary side such that the secondary side is wider (Siver et al. 2007). The valve face is typically flat.

Nupela was originally described from highelevation ponds in Papua New Guinea (Vyverman \& Compére 1991). Since its initial discovery, Nupela has been reported across Europe, South 
America, North America, Asia and Africa, typically in oligotrophic waters with acidic to circumneutral pH (Metzeltin \& Lange-Bertalot 1998; Monnier et al. 2003; Potapova et al. 2003; Siver et al. 2007; Wojtal 2009; Kulikovskiy et al. 2010).

In this article we summarize our findings on the occurrence and distribution of Nupela species in three mountain lakes during the late Quaternary period after the glaciers receded and these lakes the most spectacular attractions of Retezat National Park - formed (Urdea 2004).

\section{MATERIALS AND METHODS}

Lacustrine sediment cores were obtained from four glacial lakes for a high-resolution multiproxy study conducted in the Retezat Mts. (Magyari et al. 2009a). Lake Brazi $\left(45^{\circ} 23^{\prime} 47^{\prime \prime} \mathrm{N}, 22^{\circ} 54^{\prime} 06^{\prime \prime} \mathrm{E}\right.$; 0.5 ha; $1740 \mathrm{~m}$ a.s.l.; max. $1.1 \mathrm{~m}$ water depth) and Lake Gales $\left(45^{\circ} 23^{\prime} 6^{\prime \prime} \mathrm{N}\right.$, $22^{\circ} 54^{\prime} 33^{\prime \prime} \mathrm{E}$; $3.68 \mathrm{ha} ; 2040 \mathrm{~m}$ a.s.1.; max. $20 \mathrm{~m}$ water depth) are situated on the northern flank and were cored in 2007. Lake Lia $\left(45^{\circ} 35^{\prime} 30^{\prime \prime} \mathrm{N}, 22^{\circ} 87^{\prime} 87^{\prime \prime} \mathrm{E}\right.$; 1.3 ha; $1910 \mathrm{~m}$ a.s.l.; $\max .4 .3 \mathrm{~m}$ water depth) and Lake Bucura $\left(45^{\circ} 36^{\prime} 40^{\prime \prime} \mathrm{N}, 22^{\circ} 87^{\prime} 79^{\prime \prime} \mathrm{E} ; 10\right.$ ha; $2040 \mathrm{~m}$ a.s.l.; max. $15.7 \mathrm{~m}$ water depth) are situated on the southern flank and were drilled in 2008 (Magyari et al. 2009a). For subsampling, core sections were first split lengthwise followed by subsampling at usually $4 \mathrm{~cm}$ resolution (Magyari et al. 2009a). Subsamples were used for multiproxy analyses, including geochemical, pollen, macrofossils, cladocera, chironomids and siliceous algae. The chronology of the sediment sequences is published in part (for Lake Brazi and Gales see Magyari et al. 2009a) and some radiocarbon dates are not yet published (Lake Lia).

So far high-resolution diatom analyses have been carried out in three of the four lakes (Lake Brazi, Gales, Lia); more than 450 samples were counted. For analyses of the siliceous algae, samples were prepared by standard digestion procedures (Battarbee 1986). Aliquot-evaporated suspensions were embedded in Zrax and Pleurax. From each sample $c a 350$ valves were counted using a light microscope (Leica DM LB2 with 100 HCX PLAN APO objective and Fujifilm FinePix S2 Pro digital camera; later VSI-3.OM(H) digital camera). During the counting procedure pictures of ambiguous valves were taken; later the pictures were arranged according to the diatom genera to which they belong, and the small forms were grouped together. For

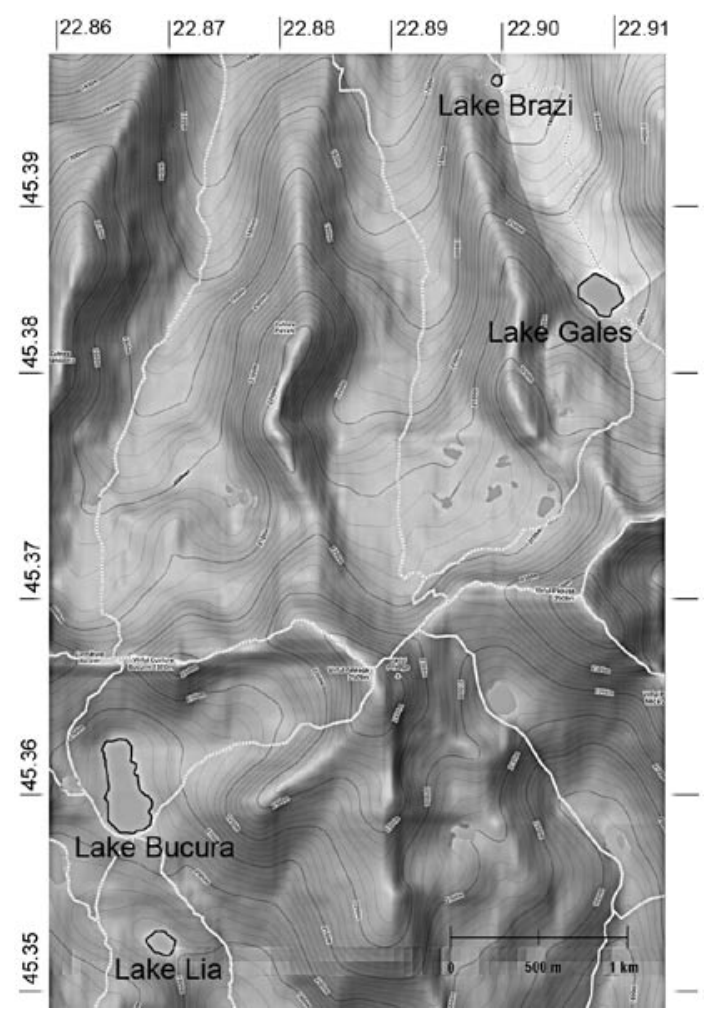

Fig. 1. Location of the studied lakes in the Retezat Mountains, Southern Carpathians.

SEM, cleaned samples were air-dried on an aluminum stub. Specimens were coated with gold-palladium using a XC7620 Mini Sputter Coater for $120 \mathrm{~s}$ at $16 \mathrm{~mA}$, and studied with a Hitachi S-2600N scanning electron microscope operated at $20 \mathrm{kV}$ and 5-8 $\mathrm{mm}$ distance. Morphological terminology follows Hendey (1964), Barber and Haworth (1981) and Round et al. (1990). Valves were measured from digital images using the camera software.

\section{RESULTS}

We distinguished eight taxa within the Nupela genus in the three studied lakes. The following taxa were found and are presented below: Nupela fennica, $N$. imperfecta, $N$. impexiformis, $N$. lapidosa, N. paludigena, N. vitiosa and an unidentified member of Nupela (Figs $19 \& 20)$. The material also yielded a new species, described formally here as $N$. pocsii. 
Nupela fennica (Hustedt) Lange-Bertalot 2004

Figs 2-4

Navicula fennica Hustedt 1962.

REFERENCE. Potapova (2010a).

Valves linear-elliptical with broadly rounded ends. Length 16-19 $\mu \mathrm{m}$, width 3.0-3.8 $\mu \mathrm{m}$, striae hardly discernible in LM; ca 35-40 in $10 \mu \mathrm{m}$. Axial area narrowly linear. Central area forms rectangular fascia. Striae radiate in middle, parallel or slightly convergent at apices. According to Potapova (2010a) the distinction between N. fennica and $N$. vitiosa is not entirely clear. On the basis of protologues, $N$. fennica differs from $N$. vitiosa by the shape of the central area, which for the first species is symmetrical, rectangular, and expanded to both valve margins.

Distribution IN THE RETEZAT MTS. Only two valves were found at $416 \mathrm{~cm}(8480 \mathrm{cal} \mathrm{yr} \mathrm{BP})$ in Lake Brazi. In Lake Gales $N$. fennica was sporadically found from $140 \mathrm{~cm}(5900 \mathrm{cal} \mathrm{yr}$ BP) to the top of the core (up to present). In Lake Lia it was recorded from $710 \mathrm{~cm}$ ( $c a$ from 14,000 cal yr BP) also up to the top of the core.

GENERAL DISTRIBUTION. Known from Finland (Lange-Bertalot \& Metzeltin 1996), and North America (Potapova 2010a).

Nupela imperfecta (Schimanski) Lange-Bertalot 1999 Fig. 5

Achnanthes imperfecta Schimanski 1978.

REFERENCE. Krammer \& Lange-Bertalot (1991: 53; fig. 31: 1-10).

Valves linear-lanceolate, apices protracted with broadly rounded ends. Length $19.8-26.0 \mu \mathrm{m}$, width $6.3-6.5 \mu \mathrm{m}$. The outline and dimensions as well as the shape of the central area and the striae pattern well fit the description of $N$. imperfecta.

Distribution In the Retezat Mts. Only two valves were found, one in Lake Gales at $172 \mathrm{~cm}$ (8500 cal yr BP) and the other in Lake Lia at $214 \mathrm{~cm}$ (5200 cal yr BP).

GENERAL DISTRIBUTION. Mongolia (Kulikovskiy et al. 2010), Europe: Taunus, Iceland, Finland (Lange-Bertalot \& Krammer 1989).
Nupela impexiformis (Lange-Bertalot) LangeBertalot 1999

Figs 6-10

Achnanthes impexiformis Lange-Bertalot in LangeBertalot \& Krammer 1989.

REFERENCES. Lange-Bertalot \& Krammer (1989: 53; fig. 31: 1-10), Potapova (2011a).

Valves elliptical-lanceolate with capitate ends. Length 14.5-17.0 $\mu \mathrm{m}$, width 4.5-5.5 $\mu \mathrm{m}$, striae not discernible in LM. Heterovalvar, the raphe is absent on one of the valves. Raphe straight. This population has slightly larger valves than given in the description, where $12-16 \mu \mathrm{m}$ is given for length and 3.5-4.5 for width, with 45-55 striae in $10 \mu \mathrm{m}$. Potapova (2011a) found valves up to $17 \mu \mathrm{m}$ in length but with valve width in agreement with the original description (3.8-4.6 $\mu \mathrm{m})$.

Distribution IN THE RETEZAT MTS. In Lake Gales $A$. impexiformis was found in seven samples: between $138 \mathrm{~cm}$ (5770 cal yr BP) and $108 \mathrm{~cm}$ (4820 cal yr BP), at $56 \mathrm{~cm}$ (3060 cal yr BP) and at $2 \mathrm{~cm}$ (120 cal yr BP), but it was not abundant in the samples. Two valves were found in Lake Lia at $503 \mathrm{~cm}(10,080 \mathrm{cal} \mathrm{yr} \mathrm{BP})$ and at $347 \mathrm{~cm}$ (7660 cal yr BP).

General Distribution. Finland, Sweden, Island (Lange-Bertalot \& Krammer 1989), Mongolia (Kulikovskiy et al. 2010); prefers oligotrophic, circumneutral or acidic (Sphagnum bogs) habitats.

Nupela lapidosa (Krasske) Lange-Bertalot 1999

Figs 11-15

Achnanthes lapidosa Krasske 1929

REFERENCE. Krammer \& Lange-Bertalot (1991: 47; fig. 27: 1-14), Wojtal (2009: 234; figs 1-5, 14-25).

Frustule heterovalvar, one valve has complete raphe but absent in another one. Valves lanceolate to linear-lanceolate with slightly elongated ends. Length 15.5-23.0 $\mu \mathrm{m}$, width 4.8-5.6 $\mu \mathrm{m}$. Striae clearly visible on both valves, slightly radiate in middle of valve and becoming radiate towards apices, 20-24 in $10 \mu \mathrm{m}$. Axial area linear-lanceolate on raphe valve, broadly lanceolate 
on rapheless valve. Central area asymmetrical, unilaterally expanded up to valve margin (rapheless valve) or almost up to valve margin (raphe valve).

Distribution IN THE RETEZAT MTS: In the Late Glacial part of Lake Gales it was found sporadically at $280 \mathrm{~cm}$ ( $c$ a 13,540 cal yr BP), $264 \mathrm{~cm}$ (12,960 cal yr BP) and $228 \mathrm{~cm}(12,040 \mathrm{cal} \mathrm{yr} \mathrm{BP})$; between $212 \mathrm{~cm}(11,500 \mathrm{cal} \mathrm{yr}$ BP) and $140 \mathrm{~cm}$ (5910 cal yr BP) the species was continuously present. In Lake Lia it was a common but never abundant member of the diatom assemblages; it was recorded between $762 \mathrm{~cm}$ ( $\mathrm{ca} 14,200 \mathrm{cal} \mathrm{yr}$ $\mathrm{BP})$ and $443 \mathrm{~cm}$ ( $c$ a $9220 \mathrm{cal} \mathrm{yr} \mathrm{BP})$. In the Late Glacial population (14,700-11,700 cal yr BP) valves markedly smaller than in the Holocene (from 11,700 cal yr BP) were found.

GENERAL DISTRIBUTION: Nupela lapidosa is a common representative of Nupela, often reported from springs having very low conductivity, low alkalinity and high oxygen concentration in the Tatra Mts (Wojtal 2013), and in aerophytic habitats (Krammer \& Lange-Bertalot 1991). It was previously reported from the Alps and Central Europe as preferring oligotrophic, circumneutral waters of low to moderate conductivity (Werum \& LangeBertalot 2004).

Nupela paludigena (R. P. Scherer) Lange-Bertalot 1993

Figs 16-18

Anomoeoneis paludigena R. P. Scherer 1988

REFERENCES. Scherer (1988: 149; figs 42-45, 72), Siver et al. (2007: 128; figs 4, 5).

Frustules isovalvar. Valves elliptical-lanceolate to linear-lanceolate, with rostrate to capitate apices. Length $10-20 \mu \mathrm{m}$, width 3-5 $\mu \mathrm{m}$. Striae slightly radiate to parallel in center, becoming parallel to- wards apices, $38-45$ in $10 \mu \mathrm{m}$. Axial area narrow. Central area variable, small, elliptical to rectangular in shape and most often unevenly spaced on each side of valve. Raphe slightly wavy with distal raphe fissures running down onto apical mantle and deflected towards secondary side of valve. Proximal raphe fissures straight and end as small teardrop-shaped pores. Areolae elliptical to rectangular, expanded along transapical valve axis, with wider opening on external surface than on internal surface. Mantle a single row of elongated areolae.

Distribution IN THE RETEZAT MTS. This species was found only in Lake Lia. LM pictures are based on material retrieved from $134 \mathrm{~cm} \mathrm{(3250} \mathrm{cal}$ yr BP) and the SEM image is based on a sample at $50 \mathrm{~cm}$ (1060 cal yr BP).

OTHER OCCURRENCES. Buczkó and Magyari (2007: 11; Pl. 4: 96 \& 97) published LM and SEM images of an unidentified diatom as Nupela sp. from Lake Saint Anna. The dimensions of these specimens are length $12-15 \mu \mathrm{m}$, width $3 \mu \mathrm{m}$, striae not visible in LM, 54 in $10 \mu \mathrm{m}$ in SEM. This form was infrequent in the Holocene sequence of Lake Saint Anna but occurred in several layers; its abundance never exceeded $2 \%$. The description, other published data and the illustration $N$. paludigena indicate conspecificity of the Nupela specimens from Lake Saint Anna and Lake Lia. As a result, our data extend the occurrence of $N$. paludigena to the Southern and Eastern Carpathians, and as far as we know this is the first European record of this taxon.

General Distribution. This species was originally described by Scherer (1988) from acidic localities in the southeastern part of the Atlantic Coastal Plain. Siver et al. (2007) reported it from the Atlantic Coastal Plain of North Carolina from

Figs 2-27. 2-4 - Nupela fennica (Hustedt) Lange-Bertalot from lake Brazi, 5 - N. imperfecta (Schimanski) Lange-Bertalot from Lake Lia at $214 \mathrm{~cm}, 6-10-N$. impexiformis (Lange-Bertalot) Lange-Bertalot from Lake Gales and Lake Lia, 11-14 - LM of $N$. lapidosa (Krasske) Lange-Bertalot, 15 - internal view of rapheless valve of $N$. lapidosa from Lake Lia (SEM), 16 - external view of $N$. paludigena (Scherer) Lange-Bertalot from Lake Lia at $50 \mathrm{~cm}$ (SEM), 17 \& 18 - LM of $N$. paludigena from Lake Lia at $134 \mathrm{~cm}, 19$ - Nupela sp. from Lake Brazi, 20 - Nupela sp. from Lake Gales, 21-25 - LM of $N$. vitiosa (Schimanski) Siver \& Hamilton in Lake Brazi, 26 - external view of $N$. vitiosa (SEM), 27 - internal view of $N$. vitiosa. Note the unilaterally deflected proximal raphe terminals (arrow). Scale bars: $2-14 \& 17-25$ (LM) - $10 \mu \mathrm{m} ; 16 \& 26$ (SEM) - $5 \mu \mathrm{m}, 15 \& 27$ (SEM) - $5 \mu \mathrm{m}$. 


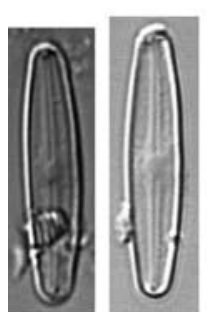

2

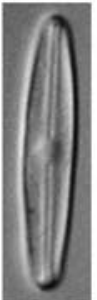

4

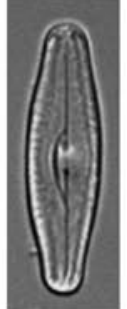

5
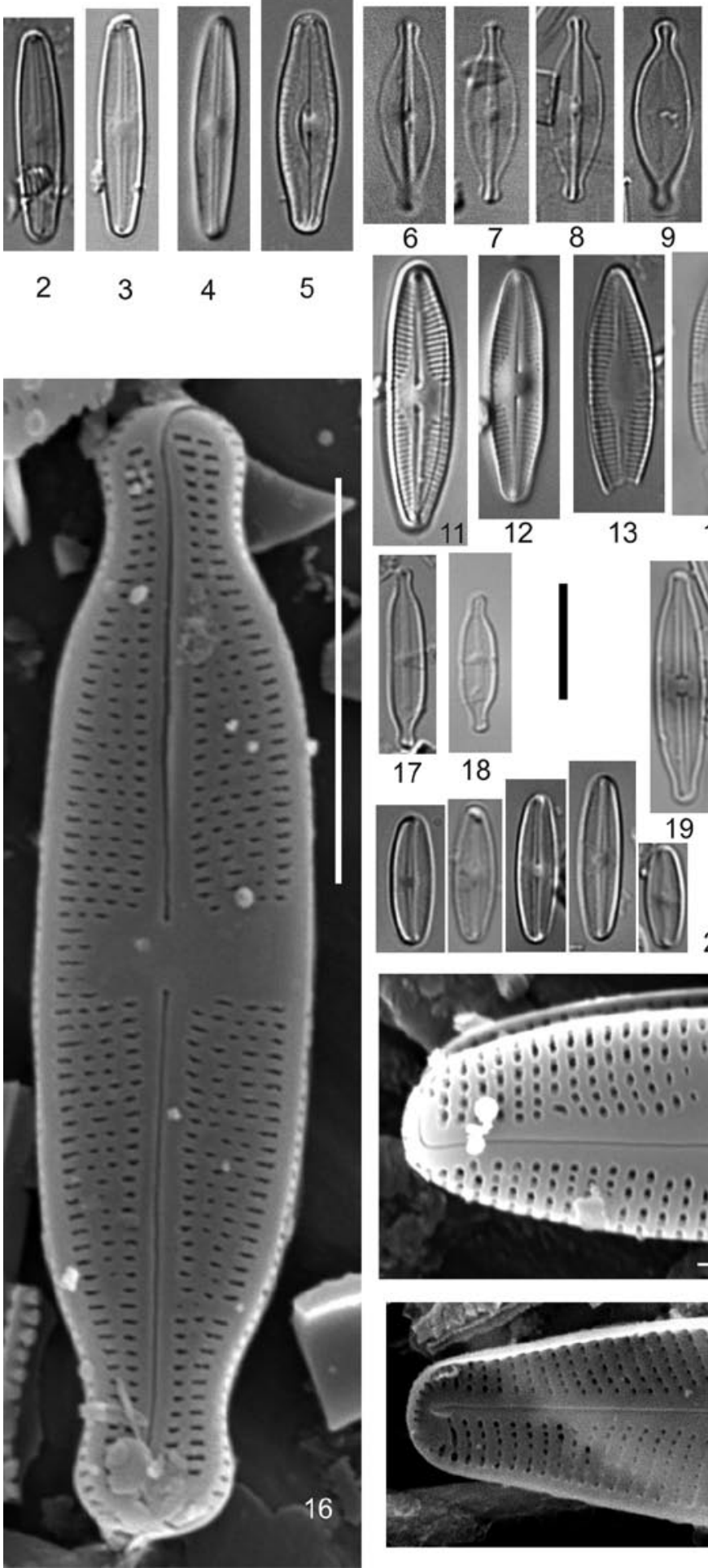

8
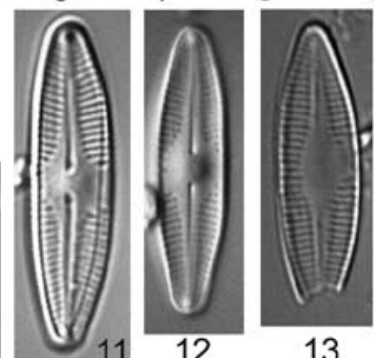

9
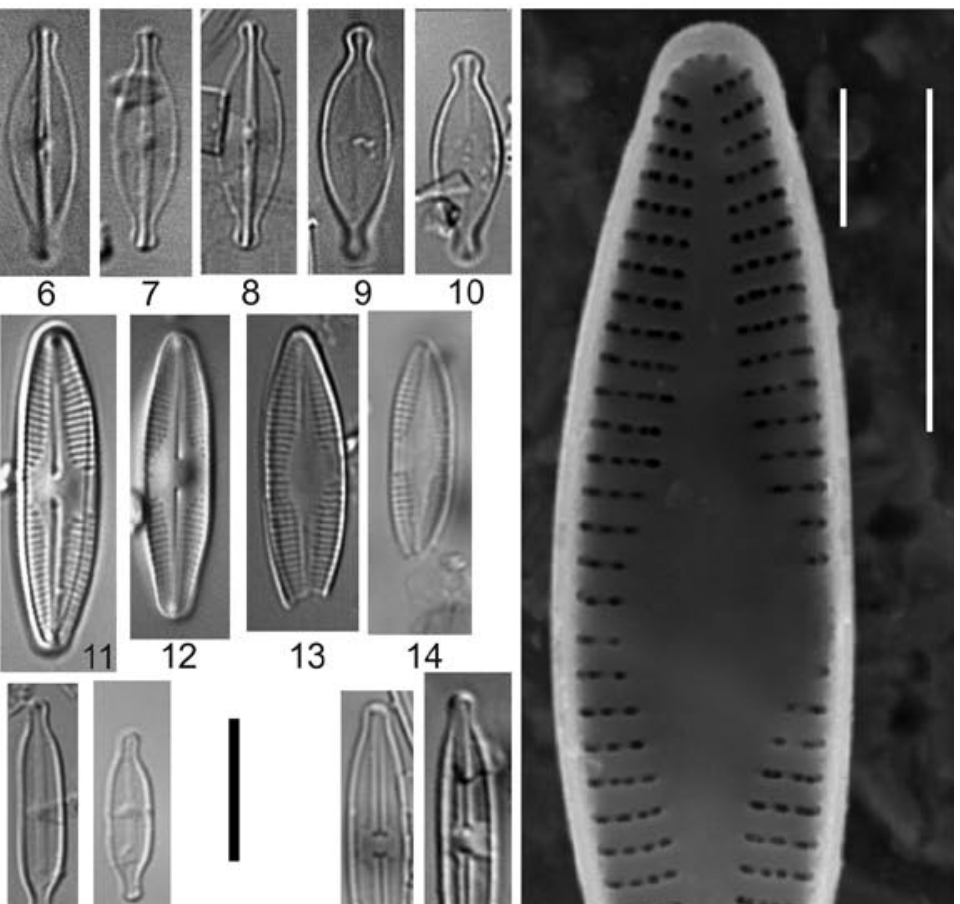

13
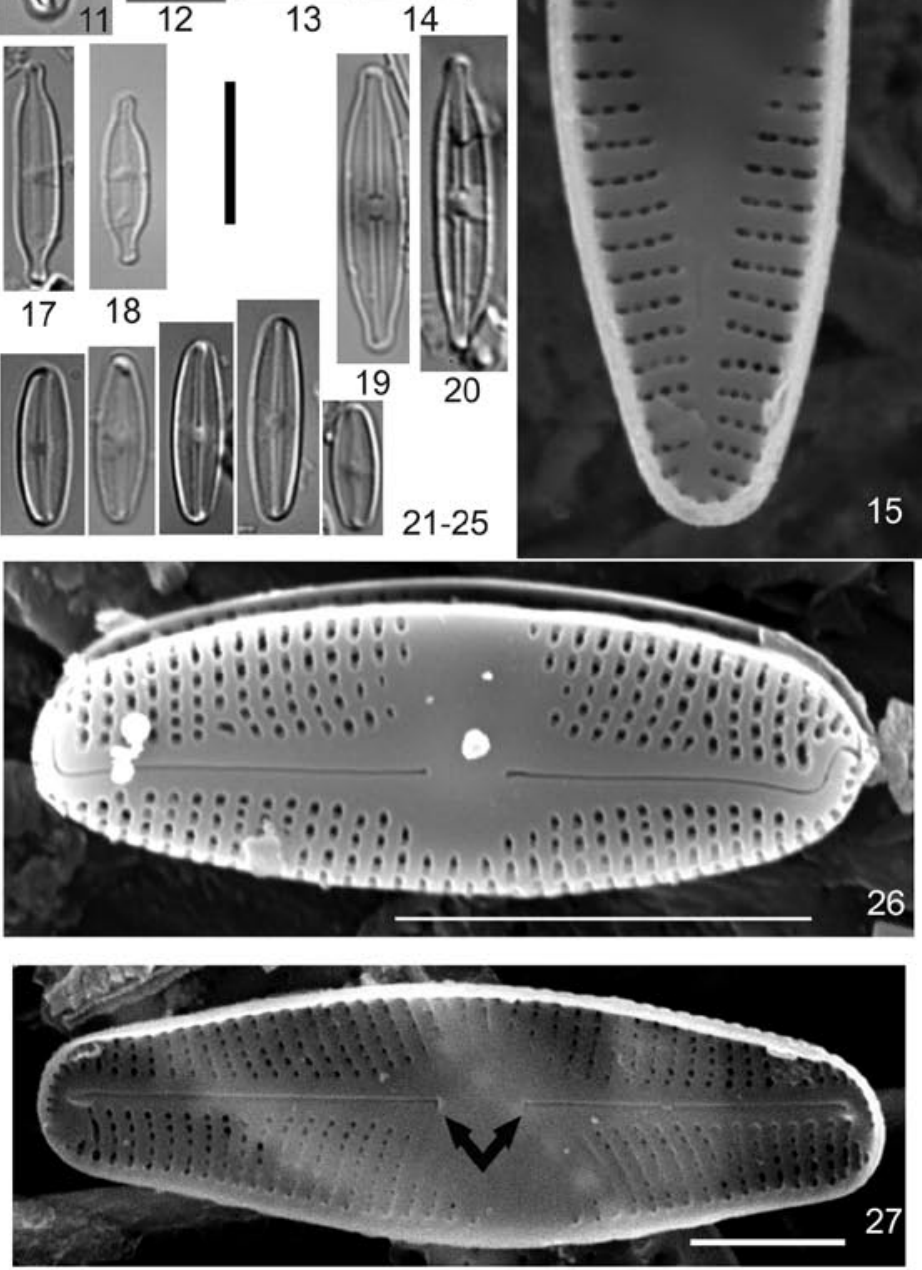
six bays, also from strongly acidic environments. Lake Saint Anna is an acidic volcanic lake with $\mathrm{pH}$ 4.0-6.4 (Magyari et al. 2009b), which corresponds with previously published data on the autoecology of the taxon. In Lake Lia the $\mathrm{pH}$ ranges from 6.4 to 6.7 (János Korponai pers. com.) According to Algaebase (Guiry \& Guiry 2013) this species is mentioned from New Zealand (Harper et al. 2012).

\section{Nupela pocsii Buczkó \& Wojtal, sp. nov.}

Figs 28-38

DESCRIPTION. Light microscopy (Figs 28-35). Valves small, elliptical with broadly rounded ends, 4.5-7.0 $\mu \mathrm{m}$ long, $3.2-4.4 \mu \mathrm{m}$ wide $(\mathrm{n}=18)$. Striae not discernible.

Scanning electron microscopy (Figs 36-38). Frustules isovalvar. Valves elliptical, with high asymmetry along apical and transapical axes (Figs 36 \& 37). Axial area rhombic-lanceolate. Central area variable, usually asymmetrical, reaching valve margin on secondary side of valve; transapically expanded large fascia on secondary side of valve and small circular area on primary side. Transapical striae slightly radial in valve middle, becoming parallel towards apices; 40-44 striae in $10 \mu \mathrm{m}$. Areolae elliptical, sometimes round, expanded transapically, with wider opening on external surface. Areolae sometimes slightly irregular and arranged in shorter rows. Ca 35-40 areolae in $10 \mu \mathrm{m}$. Externally, proximal raphe fissures slightly wavy and simply terminated, the two branches differing markedly in length. Distal raphe fissures double-curved, hook-shaped and strongly unilaterally deflected towards secondary side of valve, extending onto mantle (Figs 36-37). Internally, distal fissures simple, proximal raphe fissures T-shaped (Fig. 38). Voight faults distinct (Fig. 37).

Holotype: BP slide 2216, illustrated in Figure 28; at coordinates 62 and 105 with Leica DM LB2 light microscope; ISOTYPE: W. Szafer Institute of Botany, Kraków, Poland, No. DW 10.

TYPE LOCALITY. The new species was described from a glacial lake (Lake Brazi, TDB-1; 45 $23^{\prime} 47^{\prime \prime} \mathrm{N}$, $22^{\circ} 54^{\prime} 06^{\prime \prime} \mathrm{E}, 1740 \mathrm{~m}$ a.s.1.), sediment core $516 \mathrm{~cm}$ depth, drilled by Enikő Magyari and Mihály Braun in 2007.

ETYMOLOGY. This diatom is named in honor of the prominent Hungarian bryologist Tamás Pócs, in appreciation of his contribution to cryptogam research in Hungary, Europe and all over the world.

Morphologically the species most similar to Nupela pocsii is $N$. vitiosa, but $N$. pocsii is clearly smaller and always elliptical, while $N$. vitiosa is elliptic-lanceolate to linear-lanceolate. These two species differ in the shape of the internal raphe endings (T-shaped in $N$. pocsii and straight, simple in $N$. vitiosa), as well as in the proximal raphe endings on the external valve face. Nupela pocsii has simple while $N$. vitiosa has slightly expanding endings. These two species differ in symmetry as well. Nupela vitiosa has apical while N. pocsii has apical and transapical asymmetry.

Nupela sp.

Figs $19 \& 20$

Valves linear-lanceolate, with rostrate apices, length 19.0-20.5 $\mu \mathrm{m}$, width 3.5-4.5 $\mu \mathrm{m}$. Striae radiate, more than 35 in $10 \mathrm{~mm}$. Axial area narrow, central area large, asymmetric with rectangular fascia. Raphe straight.

We could not identify these diatom specimens; however, we hope that the publication of these yet unknown forms will help in later identification and better recognition of the diatom flora of the Retezat Mountains, as in the case of Lake Saint Anna and Nupela paludigena.

This Nupela species in Figure 19 resembles a picture published from European springs (Werum \& Lange-Bertalot 2004, Plate 26: 9), identified as Nupela tristis (Krasske) Lange-Bertalot from the Spessart Mts, Germany. On the basis of the original description of $N$. tristis (basionym: Navicula tristis Krasske 1939, described from Chile) they are not conspecific (Lange-Bertalot et al. 1996).

Distribution IN THE RETEZAT MTs: The diatom presented in Figure 19 was found in the Holocene part of Lake Brazi at $300 \mathrm{~cm}$ ( ca $3000 \mathrm{cal}$ yr BP), and the other valve (Fig. 20) was found in Lake Gales at $168 \mathrm{~cm}$ ( $c$ a $8120 \mathrm{cal} \mathrm{yr}$. BP). 

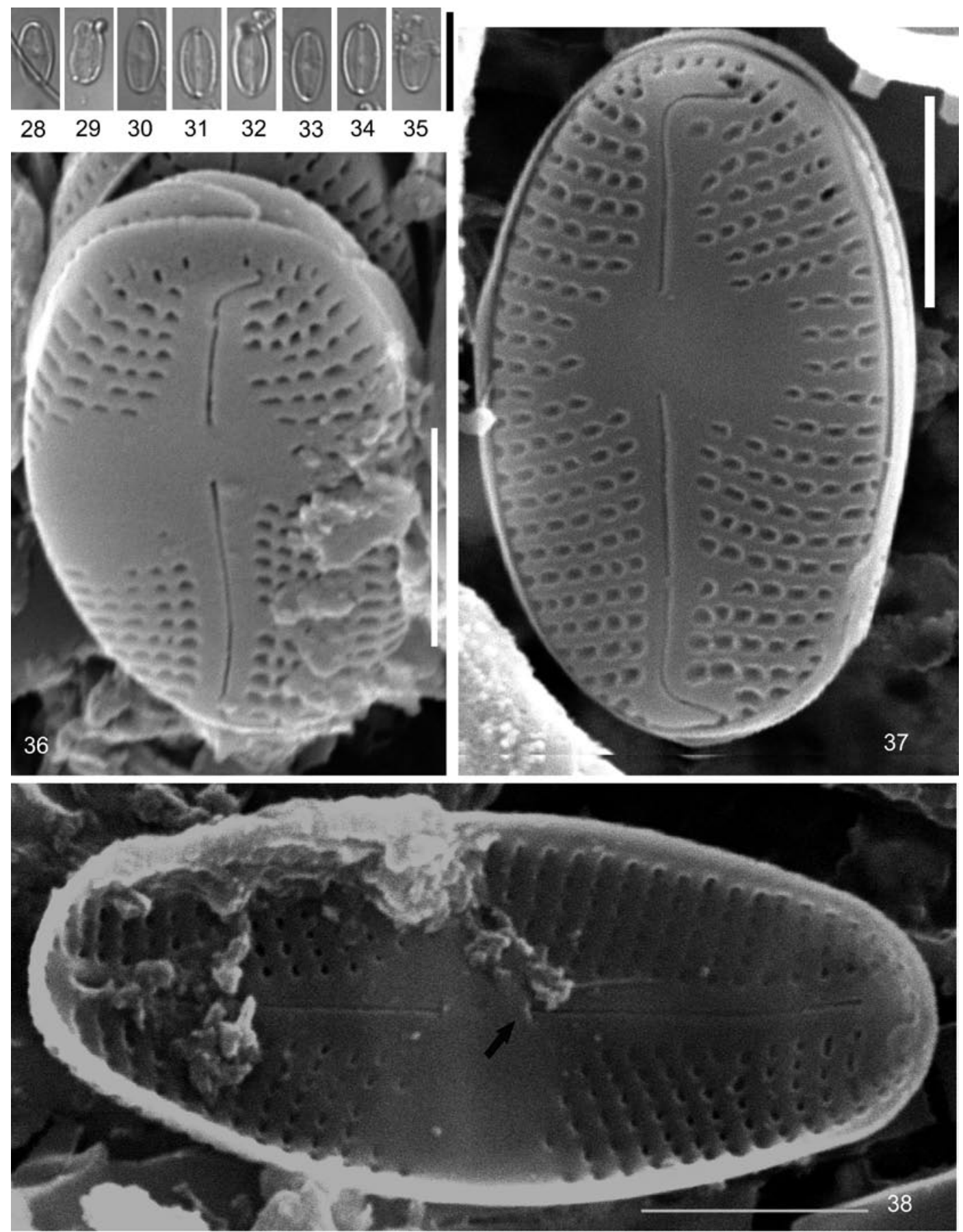

Figs 28-38. Nupela pocsii Buczkó \& Wojtal, sp. nov., 28-35 - LM of N. pocsii from Lake Brazi, Retezat Mts., Romania, 28 holotype of $N$. pocsii (slide number BP 2216), $36 \& 37$ - SEM of external view of $N$. pocsii (note the high asymmetry of central area), 38 - SEM of internal valve view (note the T-shaped proximal raphe terminal - arrow). Scale bars: $28-35$ (LM) - 10 $\mu$; 36-38 (SEM) $-2 \mu \mathrm{m}$. 
Nupela vitiosa (Schimanski) Siver \& Hamilton 2005 Figs 21-27

Navicula vitiosa Schimanski 1978

REFERENCE. Potapova (2010b).

Valves linear-elliptical-lanceolate with rounded, slightly drawn-out ends. Length 9.3-16.0 $\mu \mathrm{m}$, width 3.2-3.6 $\mu \mathrm{m}$. Axial area narrowly linear. Central area elliptical or round, usually asymmetrically expanded to one side of valve. Striae radiate in middle, slightly convergent at apices, 35-40 in $10 \mu \mathrm{m}$. Areolae transversely elliptical, covered by external hymens, ca 45 in $10 \mathrm{~mm}$. Raphe filiform, straight or very slightly curved, with slightly expanded external proximal endings.

Note. Potapova (2010b) reported smaller valves (6.5-15.0 $\mu \mathrm{m}$ long, 2.7-3.6 $\mu \mathrm{m}$ wide) of $N$. vitiosa than were given in the original description (10-16 $\mu \mathrm{m}$ long, 3-4 $\mu \mathrm{m}$ wide) by Schimanski (1978).

Distribution In the RetezAT Mts. $N u$ pela vitiosa was found in Lake Brazi in the early Holocene at $539 \mathrm{~cm}(10,790 \mathrm{cal} \mathrm{yr} \mathrm{BP})$ and $457 \mathrm{~cm}$ (ca 9260), in Lake Gales during the Holocene but sporadically, and in Lake Lia at $134 \mathrm{~cm}$ (3250 cal yr BP).

GENERAL DISTRIBUTION: Germany, Netherlands, Finland, and Canada (Krammer \& Lange-Bertalot 1991); North America (Siver et al. 2005).

\section{DISCUSSION}

During the ongoing palaeolimnological investigation of glacial lakes of the Southern Carpathians we found several small-celled diatoms belonging to the genus Nupela. Their distribution proved to be very uneven in terms of time of presence and location (Table 1). Nupela fennica, $N$. impexiformis, $N$. lapidosa and $N$. vitiosa were recorded in low abundance but their occurrence was not sporadic. Nupela paludigena, $N$. imperfecta and $N$. pocsi were very rare; only one or two valves were noted in a sample. In the modern core-top samples we recorded $N$. fennica, $N$. impexiformis, $N$. paludigena and $N$. vitiosa.
Table 1. Distribution of Nupela Vyverman \& Compère taxa in the Retezat Mountains. + sporadic; ++ rare.

\begin{tabular}{l|c|c|c}
\hline Taxon/Lake & Brazi & Gales & Lia \\
\hline Nupela fennica & + & + & + \\
N. imperfecta & - & + & + \\
N. impexiformis & - & + & + \\
N. lapidosa & - & ++ & + \\
N. paludigena & - & - & + \\
N. pocsii & + & - & - \\
N. vitiosa & ++ & + & + \\
\hline
\end{tabular}

On the timescale, Nupela vitiosa was the first member of the genus to appear in Lake Lia, at $c a$ 14,200 cal yr BP, but for the Late Glacial period (until 11,600 cal yr BP) N. lapidosa was more characteristic Nupela species in Lake Gales and Lake Lia. The valves of the Late Glacial population of $N$. lapidosa are markedly smaller than the valves found in the Holocene.

In the early Holocene $(11,600-8200$ cal yr BP; Walker et al. 2012) N. vitiosa was a characteristic diatom in Lake Brazi, while $N$. lapidosa was more abundant in Lake Lia. However, the relative abundance of the latter never reached $2 \%$. The new species, $N$. pocsii, was also found in the early Holocene.

For the middle and late Holocene (8200-4200 and 4200 cal yr BP up to the present) $N$. impexiformis was the dominant Nupela species in Lake Gales and Lake Lia, but this well-defined form was absent from Lake Brazi.

Nupela paludigena was found only in the late Holocene, after 4200 cal yr BP (Walker et al. 2012), and only in Lake Lia. No characteristic distribution of the presence/absence of $N$. fennica was determined.

Many features used to distinguish Nupela species from other finely ornamented diatoms such as Adlafia and Kobayasiella are observable only by electron microscopy (SEM, TEM). Nupela is a growing genus of diatoms whose identification to species level and even to genus level has to be done by SEM study. Further detailed investigations of the genus Nupela are required. The data presented here are a first step toward understanding diversity within Nupela in the Southern Carpathians, 
a pristine mountain habitat. During the ontogeny of the studied lakes the members of this genus replaced each other but their occurrences were always sporadic. The very low relative abundance of Nupela species prevents us from making detailed paleolimnological inferences, but their sporadic occurrence suggests that the waters of the lakes were oligotrophic and oxygen-rich.

ACKNOWLEDGEMENTS. We are grateful to Nadja Ognjanova-Rumenova (Sofia, Bulgaria) and Kalina M. Manoylov (Milledgeville, U.S.A.) for helpful suggestions on the manuscript. We thank the Hungarian Scientific Fund for financial support (OTKA 83999, NF 101362). This is Hungarian Academy of Sciences - Hungarian Natural History Museum Paleo Contribution No. 187. This study was funded in part through co-operation between the Hungarian and Polish Academies of Sciences and the statutory fund of the W. Szafer Institute of Botany of the Polish Academy of Sciences.

\section{REFERENCES}

BAHLS L. L. 2011. Nupela potapovae sp. nov. (Bacillariophyta), a lentic alpine species from North America. Diatom Res. 26: $167-174$.

Barber H. G. \& Haworth E. Y. 1981. A guide to the morphology of the diatom frustule with a key to the British freshwater genera. Freshwater Biological Association Scientific Publication 44: 1-112.

Battarbee R. W. 1986. Diatom analysis. In: B. E. BERGLUND (ed.), Handbook of Holocene Palaeoecology and Palaeohydrology, pp. 527-570. John Wiley \& Sons, Chichester, New York, Brisbane, Toronto, Singapore.

BuczKó K. \& MAgYARI E. 2007. The Holocene diatom flora of Lake Saint Anna (Eastern Carpathians, Europe). Algol. Stud. 124: 1-28.

Fourtanier E. \& KocioleK J. P. (compil.) 2013. Catalogue of Diatom Names. California Academy of Sciences. [07 Nov. 2013]. http://research.calacademy.org/research/diatoms/ names/index.asp

GuIRY M. D. \& GuIRY G. M. 2013. AlgaeBase. World-wide electronic publication, National University of Ireland, Galway. [23 July 2013]. http://www.algaebase.org.

Harper M. A., Cassie Cooper V., Chang F. H., Nelson W. A. \& BROADY P. A. 2012. Phylum Ochrophyta: brown and golden-brown algae, diatoms, silicioflagellates, and kin. In: D. P. Gordon (ed.), New Zealand inventory of biodiversity. Vol. 3. Kingdoms Bacteria, Protozoa, Chromista, Plantae, Fungi, pp. 114-163. Canterbury University Press, Christchurch.
HENDEY N. I. 1964. An introductory account of the smaller algae of British coastal waters. Part 5: Bacillariophyceae (diatoms). Fishery investigations, Ministry of Agriculture, Fisheries and Food ser. 4, pt 5, 317 pp. [Reprinted 1976 by Otto Koeltz Science Publishers, Koeningstein, West Germany].

KRAMMER K. \& LANGE-BERTALOT H. 1991. Bacillariophyceae. 4. Teil: Achnanthaceae, Kritische Ergänzungen zu Navicula (Lineolatae) und Gomphonema, Gesamtliteraturverzeichnis Teil 1-4. In: H. ETTL, G. GÄRTNER, J. GERLOFF, H. HeYNig \& D. MollenhaUer (eds), Süsswasserflora von Mitteleuropa. 2(4): 1-437. Gustav Fischer Verlag: Stuttgart, Jena.

Kulikovskiy M., LANGe-Bertalot H. \& WitKowsKi A. 2009. Nupela matrioschka sp. nov., Nupela thurstonensis comb. nov. and Nupela neogracillima comb. \& nom. nov. (Bacillariophyceae): critical analysis of their morphology. Polish Bot. J. 54: 13-20.

Kulikovskiy M. S., LANGE-Bertalot H., WitKowsKi A., Dorofeyuk N. I. \& GenKal S. I., 2010. Diatom assemblages from Sphagnum bogs of the world. Biblioth. Diatomol. 55: 1-326.

LANGE-Bertalot H. \& KRAMMER K. 1989. Achnanthes eine Monographie der Gattung mit Definition der Gattung Cocconeis and Nachtragen zu den Naviculaceae. Biblioth. Diatomol. 18: 1-393.

Lange-Bertalot H., Külbs K., Lauser T., NörpelSCHEMPP M. \& WiLLMANN M. 1996. Diatom taxa introduced by Georg Krasske, documentation and revision. Iconogr. Diatomol. 3: 1-358.

LANGe-Bertalot H. \& Metzeltin D. 1996. Indicators of Oligotrophy. 800 Taxa representative of three ecologically distinct lake types, Carbonate buffered-Oligodystrophic-weakly buffered soft water. Iconogr. Diatomol. 2: $1-390$.

MAgYARI E. K., BRAUn M., BUCZKÓ K., KERN Z., LÁsZló P., HUBAY, K. \& BÁLINT M. 2009a. Radiocarbon chronology of glacial lake sediments in the Retezat Mts (S Carpathians, Romania): a window to Late Glacial and Holocene climatic and palaeoenvironmental changes. Central European Geology 52: 225-248.

Magyari E. K., BuczKó K., JaKab G., Braun M., PÁl Z. \& KARÁTSON D. 2009b. Palaeolimnology of the last crater lake in the Eastern Carpathian Mountains - a multiproxy study of Holocene hydrological changes. Hydrobiologia 631: 29-63.

Metzeltin D. \& Lange-Bertalot H. 1998. Tropical diatoms of South America. I. About 700 predominantly rarely known or new taxa representative of the neotropical flora. Iconogr. Diatomol. 5: 1-696.

Monnier O., Lange-Bertalot H. \& Bertrand J. 2003. Nupela exotica species nova: une diatomée d'un aquarium tropical d'eau douce. Avec des remarques sur la biogéographie du genre. Diatom Res. 18: 273-291. 
Potapova M. 2010a. Nupela fennica. In: Diatoms of the United States. [21 July 2013]. http://westerndiatoms.colorado.edu/ taxa/species/nupela_fennica.

Potapova M. 2010b. Nupela vitiosa. In: Diatoms of the United States. [21 July 2013]. http://westerndiatoms.colorado.edu/ taxa/species/nupela_vitiosa.

Potapova M. 2011a. Nupela impexiformis. In: Diatoms of the United States. [21 July 2013]. http://westerndiatoms. colorado.edu/taxa/species/nupela_impexiformis.

Potapova M. G. 2011b. New species and combinations in the genus Nupela from the USA. Diatom Res. 26: 73-87.

Potapova M. G., Ponader K. C., Lowe R. L., Clason T. A. \& BAHLS L. L. 2003. Small-celled Nupela species from North America. Diatom Res. 18: 293-306.

Round F. E., Crawford R. M. \& MANN D. G. 1990. The diatoms: biology and morphology of the genera. Cambridge University Press, Cambridge.

SCHERER R. P. 1988. Freshwater diatom assemblages and ecology/palaeoecology of the Okefenokee swamp/marsh complex, Southern Georgia, USA. Diatom Res. 3: 129-157.

SCHIMANSKI H. 1978. Beitrag zur Diatomeenflora des Frankenwaldes. Nova Hedwigia 30: 557-634.

Siver P. A., Hamilton P. B., Kociolek J. P., StachuraSuCHOPLES K. \& EDLund M. B. 2005. Diatoms of North America The Freshwater Flora of Cape Cod, Massachussetts, U.S.A. Iconogr. Diatomol. 14: 1-463.

Siver P. A., Hamilton P. B. \& Morales E. A. 2007. Notes on the genus Nupela (Bacillariophyceae) including the description of a new species, Nupela scissura sp. nov. and an expanded description of Nupela paludigena. Phycol. Res. 55: 125-134.

Siver P. A., Wolfe A. P. \& EdLund M. B. 2010. Taxonomic and evolutionary implications of Middle Eocene pennate diatoms representing the extant genera Oxyneis, Actinella and Nupela (Bacillariophyceae). Plant Ecology and Evolution 143: 340-351.

SPAUlding S. \& EDLund M. 2008. Nupela. In: Diatoms of the United States. [11 July 2013]. http://westerndiatoms. colorado.edu/taxa/genus/Nupela.

URDEA P. 2004. The Pleistocene glaciation of the Romanian Carpathians. In: J. EHLERS \& P. L. GIBBARD (eds), Quaternary glaciations - extent and chronology, pp. 301-308. Elsevier, Amsterdam.

VYVERMAN W. \& COMPÈRE P. 1991. Nupela giluwensis gen. $\&$ spec. nov. A new genus of naviculoid diatoms. Diatom Res. 6: 175-179.

Walker M. J. C., Berkelhammer M., BJÖRCK S., CWYNAR L. C., Fisher D. A., LONG A. J., LOWE J. J., NeWNHAM R. M., RASMUSSEN S. O. \& Weiss H. 2012. Formal subdivision of the Holocene Series/Epoch: a Discussion Paper by a Working Group of INTIMATE (Integration of ice-core, marine and terrestrial records) and the Subcommission on Quaternary Stratigraphy (International Commission on Stratigraphy). Journal of Quaternary Science 27: 649-659.

Werum M. \& LANGE-Bertalot H. 2004. Diatoms in springs from Central Europe and elsewhere under influence of hydrologeology and anthropogenic impacts. Iconogr. Diatomol. 13: 1-417.

WoJTAL A. Z. 2009. Nupela marvanii sp. nov., and N. lapidosa (Krasske) Lange-Bertalot in Poland with notes on the distribution and ecology of the genus Nupela (Bacillariophyta). Fottea 9: 233-242.

WoJTAL A. Z. 2013. Species composition and distribution of diatoms assemblages in spring waters from various geological formations in souther Poland. Biblioth. Diatomol. 59: $1-436$. 